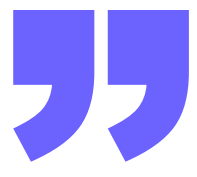

\title{
IDENTIFY THE TYPES \& REASON OF CODE MIXING FOUND IN WHATSAPP GROUP CARGO DEPARTMENT STAFF AT NGURAH RAI AIRPORT
}

\author{
Siti Rohmawati Imam Muttaqien ${ }^{1}$, I Komang Sulatra ${ }^{2}$, \\ I Made Indrawan Jendra ${ }^{3}$ \\ Mahasaraswati Denpasar University, Indonesia ${ }^{1,2,3}$ \\ rahmamuttaqien.im@gmail.com, soelatra01@yahoo.com, \\ iwanindrawan300573@gmail.com
}

Journal History

Submitted 26 th December 2021

Revised 16 $16^{\text {th }}$ January 2022

Accepted 17th January 2022

Published 24th January 2022

Keywords:

Code Mixing, WhatsApp Group, Cargo Department

\begin{abstract}
The aims of this study are to find out the types of code mixing found in WhatsApp Group cargo department by the staffs at Ngurah Rai Airport and to analyse the reason of code mixing found in the WhatsApp Group by the staff at Ngurah Rai Airport. The data were taken from chat of cargo department staff in WhatsApp Group at Ngurah Rai Airport. The method of collecting data was starting from March 1 to 30, 2021. The analysis was done by applying descriptive qualitative method with documentation. The result of this study shows that there are two types that were found in the WhatsApp Group cargo department by the staff at Ngurah Rai Airport, there are: Intra-sentential code mixing, intra-lexical code mixing and involvement in a change of pronunciation. The type of Intra-Sentential codemixing was more commonly found in chat conversations by the staffs on WhatsApp group, who stated that it was easier not to change the language in the cargo world, which primarily used English, to keep it easier for interact and avoid misunderstandings in the handover of their assignments or job desks. There are four reasons found, namely: Topic, participant, solidarity, and status. Because the relationship between employees provided information about the duties being carried out between divisions, the topic became one of the most common causes for identifying code mixing in chat chats in WhatsApp groups by cargo department staff.
\end{abstract}




\section{INTRODUCTION}

Language is a means of communication between people, where there is a social context in communication, therefore communication requires an understanding and acknowledgment of the relationship between language and the people who use it. Social context has the role of the main factor that drives us in choosing language. Just as in every community and every individual has their own language to express ideas, the values to be conveyed, which are expressed in (Julie S. Amberg, Deborah J. Vause 2009). Based on G.G. Brown 2013 "Communication is the transfer of information from one person to another, whether it is believed or not. But the information transferred must be understandable by the recipient or the interlocutor. Each country has its own national language or regional language to use in their daily lives to facilitate their communication and interaction with each other. It's the same as in Indonesia, which is famous and rich in cultural diversity, so that each region uses its own regional language in communicating between people who live in the area to maintain continuity in interaction. Behind the diversity of regional languages in Indonesia, but Indonesia remains one, the meaning is that the unifying language of the nation is Indonesian which is used by all Indonesians. In this case the role of language is a basic need for all social beings where it is not only the exchange of information, ideas or ideas that occurs but language here is a tool of cultural interaction.

In this modern era, almost most people can master more than one language, or even they mix their language by using another language to make it appear that they have value in the speaking aspect. Most of them develop their knowledge and skills in their second language, they become bilingual or multilingual who can speak more than one language at the same time. In society, we often meet people who are bilingual or multilingual, which is normal in situations where we choose between two or more codes that must be spoken. For bilinguals or multilingual, choosing is part of a routine and a skill, and deciding which one to choose and pronounce the code must be developed again. Spolsky (1998:45) said bilinguals as people who have some functional ability in a second language. And most of the Indonesian population is bilingual who often mix and match their language in their daily communication, such as they use the local language they live in and the national language is Indonesian and the international language is English. And this phenomenon we often encounter in Indonesia, where Indonesia is a destination for tourists to enjoy their holidays, as we know Indonesia is rich in tourist attractions that are very well maintained and beautiful to relieve fatigue, and what often happens is that they mix the national language. and foreign languages in their daily life with the hope that good communication can 
be established and can convey what is happening. Where this speech is classified into code-mixing.

According to Wardaugh (1986:103) the process of code-mixing occurs when a person easily uses two languages simultaneously in one sentence and moves from one language to another in one utterance. The impact of what has happened has made the number of findings from code- mixing in daily use increase, they can easily mix their language according to their needs and convey the meaning they want to convey, without them realizing that this code-mixing process is happening. with various factors such as wanting to show the background of the speaker, their status, their intelligence and some even attract sympathy from others. There are many benefits to the impact of using or knowing a foreign language, especially for the millennial genre. This code-mixing is very common in real life, around or in cyberspace such as on social media such as WhatsApp, Twitter, Instagram, and Facebook which are widely used by millennials, so many of us encounter code-mixing without them realizing that they have entered into code-mixing. Not only in social media that we often see but in everyday life we often hear speakers use language such as "let's go ke rumah $\mathrm{ku}$ " or "jangan lupa datengnya on time" which is more common is "by the way, aku mau ikutan coba makanan yang lagi viral itu. Based on the sentence above, without realizing it by the speaker that has inserted English in the speech, which means in Indonesian "let's go means ayo", "on time which means tepat waktu" and the last one is "by the way" it is means ngomong-ngomong. it is undeniable that many audiences use codemixing during the process of the interaction and that there is a mixing of languages (Indonesian - English) or (English - Indonesian). The incidence of code mixing is based on persons who are able or master more than two languages, as well as their communication with various groups, which results in the unavoidable code mixing in their daily lives and without their knowledge.

WhatsApp is a part of one of the most well-known and widely utilized social media platforms today, and it is used as a communication tool by people all over the world. WhatsApp is a smartphone instant messaging application that, based on its functionality, is nearly identical to the SMS application used on older cell phones. WhatsApp, on the other hand, does not use credit but rather internet data. And, in general, the public, beginning with workers, students, and other associations, now uses WhatsApp Group messages to form their communities, making communication between members easier and easier. There is no need to provide information through private channels to be more efficient and save time. Here WhatsApp is used as an object to collect data, where there is much code-mixing in communication that occurs in their WhatsApp group. 
The author hopes that this research provided useful and clear information to the reader, and made the WhatsApp group the object of this research. Readers can also learn terms in the world of aviation, especially the world of cargo, which supports them to learn and introduce new vocabulary.

Several previous studies about code mixing have been published throughout the progression of scientific research on code mixing, such as the first study from (Kartini, 2019) the findings of this thesis examined the types of code-mixing utilized by Sheryl on Twitter, as well as the reasons for her followers' use of code-mixing. Sheryl employs nouns, adjectives, verbs, and phrases as code-mixing forms on her Twitter account. While the dominant attitude and language attitude are the reason. The second study is connected to this article from (Hutraini, 2019) Based on this research, the Music Breakout show on Net TV examines the varieties of code-mixing based on theory (Musyken 2000) and describes the function code- mixing based on the theory of Hoffman (1991), while the findings of this investigation found 28 data including code-mixing. There were 6 utterances of insertion, 9 utterances of substitution, and 12 utterances of congruent lexicalization. The code-mixing function in the presenter's speech is then used. There were 20 statements concerning a specific issue, 1 speech about repetition used for clarification, and 1 utterance about revealing group identify in find 20 utterances.

\section{METHODS}

The researcher used a qualitative approach from Mackey and Gass (2005:167), data collection includes ethnography, interviews, diaries/journals, case studies, and observation techniques. The documentation approach was utilized to collect data in this study. As a researcher, the author needs documentation to determine the current state of the study object. Several airline WhatsApp groups are being investigated, including the Citilink WhatsApp group, FF Lion, MLC Warehouse, Air Asia, and others. Data was collected from March 1 to 30, 2021. This data collection process includes several steps, such as: (1) Monitoring and screenshots from the airline's WhatsApp group where code-mixing is employed in the chat. (2) Identifying code- mixing remarks in a WhatsApp group of cargo department staff at Ngurah Rai Airport. (3) Classification the types code-mixing based on Hoffman's (1991) theory, as well as the reason code mixing was found in a WhatsApp group by the staff, according to Holmes's theory (2013). The results of the study are presented using two methods: formal and informal methods, which are used to present on the types and reasons of code mixing. The percentage is the result of the formal finding presentation, which is considered as a part of a diagram and a table. There is no table, graphic, or symbol in the casual version. The form of description is an informal method of 
presentation. This description categorizes the types and the reasons of code mixing found by researchers in the Ngurah Rai Airport's WhatsApp Group Cargo department.

\section{RESULTS}

\section{RESULT AND DISCUSSION}

This study's findings are based on two methods: formal and informal. In the formal results presented, the author provided data in the form of tables, figures, graphs, or symbols. In the informal method, the data is presented in a narrative format in the form of text or paragraphs. The author uses the formal technique to analyze the results in a categorized table to determine the type and reasons of code-mixing in chats collected from the Cargo Department staff at Ngurah Rai Airport's WhatsApp group. The informal technique is used in Group Text Messages of Cargo Department Workers at Ngurah Rai Airport to describe the types and the reason for Code Mixing found by the staff of the cargo department at Ngurah Rai Airport. The data was analyzed based on Hoffman's (1991) explanation of the types and reasons of code mixing in Holmes' purposed theory (2013).

\section{DISCUSSION}

This research yielded a total of 64 code-mixing results. Only two types of code-mixing were discovered out of a total of three types based on the data categorizing the types of code- mixing. This process occurred due to the large number of aviation vocabularies in the cargo world that use English, so they are used to inserting what they mean and relate to their work using English without having to replace the vocabulary with another language, it occurs to make easier for the employees to communicate with another and to minimize misunderstandings when conveying information, this type is the most common type found and used by the staff. There were 22 utterances of intra-lexical code-mixing when staff used Indonesian prefixes or suffixes. Involvement in a change in pronunciation is not identified in WhatsApp chats because this analysis is part of the text, not the speech. There are 58 data for the reason of the topic in the table data listed for the reason for the finding of code-mixing. This occurs because in the WhatsApp Group chat that was discussed or conveyed regarding the delivery and handover of the task or work being handled. The reason for participation was not found in this research, because there were no new members who did not know the language or delivery of the task handled by the employees. The following are examples and descriptions of the types of code-mixing discovered in the WhatsApp Group message cargo department at Ngurah Rai Airport, as well as the reasons for it found: 


\section{Intra-Sentential Code Mixing}

\section{Data 1}

Cargo BC 1.2 ex QG-681 sudah di terima di Incoming dengan keadaan good condition dan masih nunggu proses $\mathrm{P} 2$.

(Cargo BC 1.2 ex QG-681 has been received at Incoming in good condition and is still waiting for the $\mathrm{P} 2$ process.)

Based on the sentence above, it can be concluded into the type of sentential code- mixing, wherein that sentence you can find a lot of codemixing that is inserted and the process occurs because of the mixing of languages between Indonesian and English in one sentence. as in the word "cargo" which means "muatan" in Indonesian which is intended to explain the cargo on the QG-68 flight. "ex" which means "bekas" in Indonesian and explains that the former cargo from flight QG-681 has been received in good condition. "incoming" which means "kedatangan" in Indonesian, here is meant regarding the cargo that has been received at the incoming warehouse. "Good condition" which means "keadaan baik" in Indonesian the meaning of this phrase is to explain that today's cargo of the former flight QG-681 has been received by the incoming team in good condition. From the utterance is inside to reason of topic which is the discussion regarding a shipment that was received in good condition by the incoming team.

\section{Data 2}

1 piece's baggage arrival ada yang pecah dari pesawat sudah info avsec duty bapak Danang.

(1 piece of baggage arrival, something broke from the plane and the avsec duty Mr Danang has been informed.)

Based on data 2, it belongs to the type of sentential code-mixing where the process of mixing the language between Indonesian and English occurs at the beginning and end of the sentence. evidenced by the phrase "1 piece's baggage arrival" which means "1 potong bagasi kedatangan" in Indonesian and explains that on that flight there is 1 piece of broken arrival baggage. the second phrase "Avec duty" which means "petugas keamanan" in the Indonesian language which describes the discovery of 1 piece of broken luggage and has been reported to Mr. Danang as the security officer on duty at that time. It concluded into reason of topic because based on the above utterance proven by conveying their information about there is baggage that has been found broken and has been reported to the security officer on duty, and this process is in conformity with the procedures for dealing with this situation. 


\section{Data 3} Thanks

Selamat pagi all, dibantu 6 gerobak kosong untuk flight pagi ini.

(Good morning all, assisted by 6 empty carts for this morning's flight.) Thankyou

Based on this third data, it can be concluded that the third data grouped into Intra Sentential Code-Mixing is found from speakers mixing and matching Indonesian and English or inserting English words in Indonesian sentences which are more dominant, such as the word "all" which means "semuanya" in Indonesian where the meaning of the word greets the members of the group. and the next word "flight" which means "penerbangan" in Indonesian where it means that the speaker asked for a request to bring 6 empty carts for this morning's flight. and the last word is "thanks" which means "terimakasih" in Indonesian, the word thanks itself here conveys an expression of gratitude to the members of the group for their help. Shown by the speaker's request for an empty cart to prepare the cargo. Because the airline has all responsibility and makes all decisions, the speaker as warehouse staffis obligated to request the cart from the airline. It was found that the interaction between the airline as the one who has the authority and the warehouse staff is part of a good cooperative relationship by other parties.

\section{Data 4}

Dibantu infonya ya kalau sudah keliatan offload di QZ-7531 nya yang mana aja. 7531.)

(Please be informed, which part if there's an offload on the QZ-

Based on the fourth data, the writer finds that the speaker inserts the English word "offload" in the middle of the utterance, despite the fact that the utterance is dominant in Indonesian. It is stated that the mixing of English words in an Indonesian speech is included in intra-sentential code-mixing because the mixing occurs in the middle of the sentence according to the fourth data. the word "offload" which means "bongkar muat" in Indonesian here is designed to combine codes to express the meaning of speech using language commonly used in conversation to explain if there is an unloading of cargo on flight QZ-7531 to be informed to the airline via WhatsApp group. The proper reason for the utterance is classified as topic because it discusses the unloaded cargo on flight QZ7531, and status because the interaction between warehouse staff provides information about the unloaded cargo to the airline as a final report on the flight. 


\section{Data 5}

Supervisor tolong brief lagi team operational dan tolong di check sebelum ULD yang terisi cargo ditarik oleh Gapura ke apron.

(Supervisor, please brief the operational team again and please check before the ULD filled with cargo is pulled by Gapura to the apron.)

In the speech from the fourth data, there is a lot of code-mixing and code-mixing including the Intra-Sentential type because the language mixing between Indonesian and English occurs at the phrase border. The term "supervisor" which means "pengawas" which is intended for supervisors of the operational team, "brief" means "arahan" which is intended to give direction to the operational team to better handle their work, "operational team" means "time operasional" as an employee of the company. "Check" which means "mengecek" is intended for supervisors and operational teams who are tasked with double-checking in handling their work. "ULD" which means "container for baggage or cargo". "cargo" which means "muatan" and the last one is "Apron" which means "landasan atau parkiran pesawat. The reasons for the topic were found in the fifth data with evidenced by the utterances, which is discussed a need for the repeated instructions to increase employee performance.

\section{Intra-Lexical Code Mixing}

\section{Data 1}

Planningnya masih negative pak. Nanti diupdate lagi kalau mendadak ada ya.

(Sir, the planning is still nil. If there is a new booking list, it will be informed immediately.

The writer discovered that Intra-Lexical Code Mixing happens in the border based on the data utterance. The words "Planingnya \& diupdate" in the preceding sentence demonstrate this, with the English word "planning" having the Indonesian suffix "nya" and the term "diupdate" having the Indonesian prefix "di." The suffix "nya" refers to the state of cargo planning which was not scheduled on that particular day. The suffix "di" refers to the updating of information when a new or updated booking is made. It may be inferred that, based on the information provided above, the reason is topic based on the utterances which explained there is currently no plan for cargo shipping. 


\section{Data 2}

Team KMLC sudah ada checklistnya kah

(KMLC team, is there the checklist)

From the previous data, it can be observed that the intra-lexical code mixing occurs near the boundary. This can be seen in the phrase "checklist" in the previous line, which combines the English term "daftar barang / item" with the Indonesian suffix "nya" which means "list of items" in Indonesian, and the suffix "nya" explains that to send a list of items into WhatsApp Group from details of the shipment plan that will be departed on the flight. According to the above utterances, there is a request to send details of the report from the shipment that will depart in the next few hours and including into reason of topic.

\section{Data 3}

Team Unex nanti tolong dimonitor yan offlodan KNO mau di tarik ya

(Please keep an eye on which KNO offloaded dest will be pulled later, Unex Team.)

It's called Intra-Lexical Code Mixing because it happens at a boundary, as seen by the words "dimonitor \& offloadan." Which is the Indonesian prefix "di" for "dimonitor" and the Indonesian suffix "an" for "word offload" in English, where do the words "monitored" and "offloaded" from The suffix "an" specifies the section of the unloading that occurs, and the prefix "di" explained the circumstances of the shipping to the aircraft. The researcher grouped the utterance into topic reason, because the utterances is discussed to monitoring offloaded shipment dest KNO.

\section{CONCLUSION}

When conversant use two or more languages simultaneously to the point that they move from one language to another in the course of a single utterance, this is known as code-mixing. The types and reasons for code-mixing have been analysed in this study using data sources stemming from chats on the WhatsApp Group cargo department by staff at Ngurah Rai Airport. According to Hoffman (1991), there are three types of code-mixing: intra-sentential code- mixing, intra-lexical code-mixing, and involvement in a change of pronunciation. In this analysis, only two of three types of code-mixing were found. Intra-sentential code-mixing yielded 42 results; this type is data the most commonly found in the WhatsApp Group cargo department by the staff. This analysis is part of the chat via WhatsApp Group text and not on speaking, it is making types 
involved in a change of pronunciation were not found in this analysis. and received 22 data for the type of intra-lexical code-mixing. Meanwhile, the reason for the staff's code-mixing in WhatsApp Group messages comes from the Holmes theory (2013). There are four reasons why people mix up their codes, they are: Topic, status, solidarity, and participants. Because it is based on the data in this study, which is enhanced by chats related to their daily job desk, the topic that is most commonly found in WhatsApp Group messages by the staff. The researcher obtained 5 data for reasons of status, 1 data for reasons of solidarity, and the reason participants were not identified there were no new members who did not understand the workers process language or rules.

\section{REFERENCES}

Amberg, Julie S \& Vause, Deborah J. American English:History,Structure,and Usage.USA:Cambridge University Press

Brown, G.G.(N.D). Definition of Communication. Available http:/ / communicationtheory.org/definition-0f communicationsAccessedJune3,2013.

Holmes, Janet. 2013. An introduction to sociolinguistics. Abingdon: Routledge.

Hoffman, C. (1991). An Introduction to Bilingualism. New York: Longman.

Hutraini, (2019). Mixture Of Indonesian-English Code Used by Break Out Music Program Presenters

Kartini, (2019) Code Mixing used by Followers Sherly Sheinafia (CASE STUDY OF ANAK JAKSEL LANGUAGE TREND).

Mackey, Alison and Susan, M. Gass. 2005. Second Language Research 'Methodology and Design'. Lawrence Erlbaum Associates. United State of America.

Spolsky, B. (1998). Sosiolinguistics (Vol.1). Oxford University Press.

Wardhaugh, Ronald. 1986. An Introduction to Sociolinguistics. Oxford: Blackwell Publisher. 